56433

- 28 
133 


\section{Beautify the Lawn to Reflect Your Personality}

The Ninth

of a Series of Monographs

on the Improvement of

Plant Life

ISSUED BY

The Luther Burbank Society SANTA ROSA, CALIFORNIA 


\section{FOREWORD}

There is a crispness in the home grown Lettuce which the green grocer neither keeps nor sells; a delicacy of flavor and an evanescent bloom in the home grown Grape or Plum, which money spent with the fruiterer can never buy. A fresh fragrance and undrooping charm in the home grown Rose, which even the most skilled florist cannot preserve; and above all, there is a joy in the production of our own vegetables, our own fruits and our own flowers - a joy in making our door-yards blossom and bear, a joy in making our own soil yield, which far exceeds the profits our gardens give.

It is the hope of the Luther Burbank Society that this series of Monographs, with their simple, practical instructions, will be of help, not alone to

$\therefore \quad$ those who now have kitchen-gardens and front-

$\therefore \quad$ yard flower-plots - but to those, as well, who do not yet know the allurement of the home garden, thus opening up for them this great field of undiluted pleasure. 


\section{BEAUTIFY THE LAWN TO}

\section{REFLECT YOUR PERSONALITY}

$\mathrm{I}^{\mathrm{T}}$

$\mathrm{T}$ is emphatically true that the things around us in Nature are our chief teachers in the world of beauty.

The things we see in the big outdoors are the great themes of all art. Painting, poetry, and music endeavor to interpret to us what we may see face to face. We may visit a great art gallery or hear the best music; but every day we have the everlasting hills. "Occasionally a line of poetry will stir our whole soul," says Frank Waugh, "but every breath of wind in the pine trees can tell the same story."

And not only is this true in the world of beauty but the power of environment upon every living species has been accepted as the fundamental law of life. We have found that we are able to select, create or regulate this outside influence. It is this created environment that reflects our personalities. 
In every community there are people whose personalities are reflected in their homes. Even though they may be secluded in their habits, and may not be in close touch with their neighbors, their homes are pointed out as the "prettiest places in town" and they are recognized as citizens to be commended for their civic pride and enterprise.

It was for this reason that Jim Phetteplace was the most talked of man in Holbrook. He lived on the main street of the town and no one passed his home without taking particular notice of it.

Jim spent considerable time in keeping up the lawn and flowers, it is true, but it was well worth while, because in addition to being the most talked sf man in the place, he was also one of the happiest. He enjoyed every minute devoted to the beautifying of his little "nest."

Phetteplace's home was indeed a picture. The bungalow of simple design was smoothed into the back-ground by a border of shrubs and flowers, and a top-covering formed by three mammoth oak trees, two of which were near the rear, the other one standing just behind the house, reached above the roof just high enough to produce the proper symmetry.

Along the curb were four elm trees, so perfectly 
developed that a person driving along the road could not help but enjoy three delightful vistas of the house. No matter from what angle the home was viewed, it was attractive. It reflected Phetteplace's personality and this reflection brought out the harmony and happiness of his life.

There was nothing unusual about the bungalow, nothing particularly unique about the trees or the flowers. The lawn was not much different from any other good lawn, but it was the combination of all these that produced the picture that so impressed the passer-by. On every side was harmony; on every side was depicted the poetry of nature.

The grass-sward, or lawn itself, was wide and deep. The house sat back from the road some fifty feet. Perhaps you would not call a fifty foot lawn a large lawn, but lawns, you know, must be laid out according to the size of the grounds, and Phetteplace's place was a small one.

The conventional yard fence had disappeared. There was a single path that lead up to the front door of the bungalow-not a straight path with sharp angles, but a gracefully curved one. It was a "natural" path. Nature does nothing stiffly or on abrupt or rigid lines.

The path was made of stones placed some 
distance apart, unlike an ordinary side walk. There were patches of grass between each two and they might have been called "stepping stones." The lawn mower ran over their edges without difficulty because they were all placed flush with the top of the soil.

At first glance it appeared that the bungalow was built without corners. The sharp angles were covered by climbing vines and tall shrubs so that the entire building blended, as it were, into the picture.

The entrance to the house was wide and hospitable. Pots of drooping vines were set on either side of the entrance and vines covered the porch posts and seemed to invite one to the comforts within.

There were no plants or trees in the lawn. The only object that interfered with its continuity from one end to the other was the path of stepping stones. The grading indicated that Phetteplace not only had a good knowledge of landscape gardening but also an intuitive artistic conception of the best effect that could be produced under existing circumstances.

A more simple arrangement could hardly be imagined, yet everyone admitted that no lawn could have been more attractive. Beginning at the 
side walk, the edge curved gently, following for a short distance the contour of the path, then it dodged in between two bushes and from there on followed a rather irregular course to the edge of the bungalow. A low growing, weeping elm bounded it there and the drooping branches of this tree hid the trunk and blended in with the delightful green of the grass.

On the other side it was of similar arrangement, but had an entirely different outline. The boundary was made in curves and without any angles of any kind. Even the connection with the wide walk was smoothed away by a dwarf lilac bush.

So simple was the picture that the onlooker felt that it would be an easy matter to duplicate it. It was the result, however, of a great deal of patient and painstaking labor. Just as the painter of a picture requires months of thought and labor to produce his best work, so the building of this home represented months. of careful planning and painstaking execution.

When Phetteplace bought his home, it was in a very rundown condition. A wabbly fence divided his lot from the next one. On the other side was a ragged hedge that had received no attention since it had been put in. The house itself was dilapidated and what passed for a lawn was overgrown with weeds. 
Phetteplace first sketched the picture of his ideal home in his mind. It was only an outline, but it was the beginning of the picture. Each day he added something to it. New ideas came to him as the work progressed. After one bush had been planted and had made some growth, an opening for another appeared.

The lawn itself was made anew. The first work was a work of destruction. All of the soil was turned over and the lawn was made to look more like a vegetable garden than anything else. The weeds were turned under, and the soil was allowed to remain this way for sometime. Then a liberal coating of rotted barnyard manure was applied and worked into the soil by a series of spadings, and water was applied every morning for several weeks.

After the soil had been allowed to dry for three or four days, it was spaded up again and the lumps pulverized. The treatment from this time on was a continuous process of pulverizing, fertilizing and leveling. No seed was sown until the surface was as nearly perfect as Phetteplace could make it.

The stepping stones had been arranged and placed on good foundations and the soil had been leveled and firmed about them. The outline of 
shrubbery had been arranged and the bushes and flowers about the house planted.

Lack of pure grass seed, and the right variety is one of the chief causes of the failure and uncertainty of lawns. So Phetteplace was careful about his combination. It consisted of Kentucky Blue grass, Red Top, and English Rye grass. Kentucky Blue grass makes a good lawn, but this being rather a slow growing variety, the others were sown with it to give the lawn an earlier start.

About a month after the seed was sown the lawn was an attractive green. The rye grass made its first appearanee, but it soon spent its course. The Red Top then covered the surface. This was finally overgrown by a thick growth of Kentucky Blue grass, which by its strength, helped by the greater time it had had for development, overshadowed the two other varieties.

The combination used consisted of twelve pounds of Kentucky Blue grass seed, five pounds Red Top, and three pounds English Rye grass. The seed was sown rather thickly and was carefully raked into the thoroughly pulverized surface.

From the time the seed was sown, no weed ever had an opportunity to make a start. Phetteplace was on the lookout every morning and his eye had been so thoroughly trained that he could 
see the first outcropping of a weed, even though it might be smaller than the grass blades that surrounded it.

He knew most of the weeds by name, too, and exactly how deep the roots extended. It wasn't the top of the plant that interested him so much, but the roots. He always made his weeding count, and figured that it was never neeessary to perform a task more than once if it was done right the first time.

On the north side of Hollorook there is another home quite as well known among the town people as Phetteplace's. It has an extensive lawn in front of it-larger than Phetteplace's - but one would not be attracted by its beauty as he passed by.

There has been work done on this northside home, it is true, and the owner spends almost as much time and labor on his grounds as does Phetteplace, but his work does not count for much because his plans have been misdirected from the outset.

As in Phetteplace's little garden the personality of the owner is reflected in his home surroundings, but it isn't the same sort of personality. He is a carcless man. He doesn't seem to understand that a job imperfectly done must be done over again at greater cost. He doesn't devote his time to 
beautifying his gromnds because he enjoys it, but because he considers it a sort of necessary evil.

Although the size of this "other man's" lawn is some 200 feet each way, the space for grass is so taken up by the excessive planting of shrubs and flowers that he seldom ever uses the mower. When the grass is cut it is done with a hand sickle.

In front of the place is a neglected and broken down fence. The gate stands ajar, balaneed on a single hinge. The pickets are out of place and two or three of the posts have rotfed off and allowed the fence to fall.

The shrubs and flowers have been planted where the lawn should be and the sharp angles of the house make it stand out like a barn on a barren hilltop.

The flower's, when they do bloom, look weak and sickly. The colors do not harmonize at all, eren the plants themselves are of such a variation in height that there is no harmony even when the blossoms are not to be seen.

Once upon a time a circular bed had been planned in the lawn; stones were piled around the edges, and dirt thrown into the ecnter. Now this bed stands as a monument to the carelessness of the owner rather than as a tribute to his genius as a landscapist. 
But let us get this depressing picture of the careless man's place out of our minds and go back to Phetteplace and his pretty home. Get it fixed so firmly in your mind, that you will duplicate it in your own home. The lawn is bound to reflect your personality unless you hire some one else to take care of it, and if you have a lawn made by a careless workman, it will probably reflect his personality instead of your own.

This life is too short to neglect the wonderful benefits that come from having a real home in the country. No matter what your circumstances, you cannot afford to live in a city flat, nor can you afford to work so hard at your business that you will not have time to care for your home.

If you do either of these, both your business and your body will suffer. The body needs the recreation that comes from a close touch with Nature. Your business needs the best service your mind and body can give it and if you get away from Nature altogether you probably will not be capable of giving the mental and physical service your business demands.

There are, of course, choices in the selection of soil for a good lawn, but sometimes we must content ourselves with the kind of soil that we can get rather than the kind that we know is best. There 
are two or three general principles that apply alike to all kinds of soils. The methods of applying these principles, however, vary according to the kind of soil in which the seed is to be sown.

The grass roots must have a firm foundation. They must grow in a soil that will retain sufficient moisture to feed them, but still not hold the water so persistently that the roots will die from the excess of moisture. If the soil should be of this nature, some means must be taken to drain it.

Sometimes it is worth while to cart away the surface soil and replace it with a mellow loam that is just right for the seed. This, of course, is expensive and should not be done if there is any way out of it.

When it is done, it is usually necessary to take away the soil to a depth of from a foot to eighteen inches all over the plot to be planted. A particularly ideal seed bed can then be made if a mellow, black, rich soil is secured.

Work in plenty of fertilizer and plenty of moisture with the soil and see that it is well settled and packed before the seed is planted. If this is not done there will be settlings here and there making little hills or valleys over the surface. If there are any pipes to be laid beneath the lawn, this work should be done before the seed is planted 
and the holes well packed and the soil thoroughly settled before the lawn is started.

A friend of the writer has found the following method a good way to "make over" an old lawn. A stick about an inch in diameter and three feet long was sharpened at one end and driven into the earth a couple of feet below the surface in different places. Into the holes thus made was tamped a rich mixture of fincly powdered fertilizer composed of hard wood ashes and bone meal. After filling the holes they were thoroughly soaked with water. Little pieces of sod were then fitted onto the holes and packed down with the back of a spade. This added food started the grass and made a new lawn in a short time.

You should be very cautious regarding the purchase of grass seed. Unfortunately not all dealers who have seed to sell are entirely honest and so one must know something about grass seed before he buys it. It is a very easy matter to add chaff and sweepings to seed and they increase the weight and greatly decrease the value. Moreover, lawn seed is pretty expensive and when you buy chaffdoctored seed you pay as much for the chaff as you do for the good seed.

The right way to buy grass seed is to secure samples of the different kinds of seed from differ- 
ent dealers. Take very small amounts of the various samples of the same kind of seed and place them in small piles in a row. Flatten them out with a knife blade so that every seed can be examined carefully. At first glance you will see considerable difference in the samples and if you use a small magnifying glass or reading glass you will be able to notice even a greater difference.

Some samples will be composed of plump seeds with a healthy appearance. Others will be partly plump seeds and partly chaff. Of course, there will be some foreign matter in every sample, but the sample that has the least in is the one that is most valuable.

This experiment will teach you the real shape and characteristics of the different kinds of seed, and if you give it some study you will find it greatly to your advantage. Remember that when grass seed is planted it is sown-not for a single year's crop-but for all time to come and should be right in the beginning.

There are many kinds of grass seeds suitable for lawns, each with a special use. Kentucky Blue grass (Poa pratensis) is the best all round grass for lawns. It grows slowly but is vigorous and can be grown in almost any kind of soil, except in one strong in acid. It thrives in the south and north, in the east and west. 
Red Top (Agrostis vulgaris) starts its growth more quickly than Blue grass, but is not so good for a permanent lawn grass. It has the advantage of being unusually well adapted to sandy soil. It is good to sow under some conditions with Kentucky Blue grass.

English Rye grass (Lolium perenne) is also a rapid growing variety and produces almost immediate results on a good soil. For this reason it makes a good combination with Bluc grass for it scrves to give a pleasing appearance to the lawn until the Blue grass gets a start.

Various-leaved Fescue (Festuca heterophysia) is especially well adapted to shady spots and moist places. Sometimes there are places between the buildings or under large trees where the blue grass does not get sufficient sun to thrive as it should or there may be a very wet soil that cannot be properly drained. It is on these spots that the Fescue should be used.

Rhode Island Bent (Agrostis canina) is one of the creeping grasses and is especially well adapted to sandy soil. Very often there is splendid use for it on a sandy terrace or slope.

Creeping Bent (Agrostis stolonifera) is also good for sandy soils and is largely used for sandy 
banks. It makes a good combination with Rhode Island Bent.

Crested Dog's Tail (Cynosurus critstatus) is another variety especially adapted to slopes and shady spots. It forms a compact sod and does not need quite so much mowing as some other varieties.

Wood Meadow grass (Poa nemoralis) is a hardy grass used considerably in northern climates for shady places.

Red Fescue (Festica ruba): When other grasses fail because of the poorness of the soil this is the variety to plant. It thrives even on gravelly banks.

White Clover (Trifolium repens): While this is often found in an open lawn, it is not to be especially recommended for this purpose. It is better for slopes. It does, however, make a quick start when the soil is just right for it.

Sheep Fescue (Festuca ovina) is another variety especially adapted to light and dry soils.

You will see by this list that the only real standard lawn grass is Kentucky Blue grass. The others are recommended primarily for special uses. The main problem then is to select the best seed of Blue grass.

As has already been suggested, samples of seed 
should be secured from different houses and examined. After you have found the sample that seems best from a physical examination, give it a germination test. Sometimes seed that is old or that has not been properly treated will look healthy but may not have the power to germinate.

In order to be sure on this point, count out a hundred or a thousand seeds, all of which appear to be normal, and place them on a plate between two damp blotters. By keeping the blotters damp, the seeds that are really alive will soon germinate. The germinating seeds must be kept in a place not colder than an ordinary even temperature.

As soon as the tiny seeds throw out shoots long enough to be readily distinguished, the number of seeds germinating should be counted. This will give the percentage of vitality and will indicate the real value of the seed.

You cannot expect every seed to grow, of course, but a large percentage of them should grow. If you find that half the number of seeds have failed to germinate, do not buy the seed. If you must use seed that is weak in germination you must increase the amount sown according to the percentage of germination. If only $75 \%$ of the seed grow it would be necessary to use one-fourth more seed than had been originally planned. 
As has already been suggested, it is often a good plan to sow a mixture of two or more kinds of seed in order to give the lawn a good start. A few combinations are suggested here:

Kentucky Blue grass, twelve pounds

Red Top, five pounds

English Rye grass, three pounds

This quantity should make a bushel and the seed should be sown at the rate of three and onehalf or four bushels per acre.

For a real shady spot, the following mixture ought to succeed:

$35 \%$ Kentucky Blue grass

$35 \%$ Wood Meadow grass

15\% Various-leaved Fescue

$15 \%$ Crested Dog's Tail.

Where it is necessary to use quick growing grass to prevent the shifting of the soil on a steep slope, the following combination will be useful:

$30 \%$ Kentucky Bhue grass

$30 \%$ Rhode Island Bent

$25 \%$ Creeping Bent

10\% Sheep Fescue

$5 \%$ White Clover.

Do not omit the White Clover, for it is very essential in this particular combination. Even if some of these varieties do not find the location 
congenial, it is almost sure that the others will and the sowing will be a success. If only two varieties are sown at a time, they might be just the ones that were not adapted to the conditions and so the sowing would be a failure and you would have no lawn until the next season.

It is not a simple task to sow grass seed. The slightest wind blows the seed to places where you do not want it. One of the worst mistakes that can be made in sowing grass is to allow it to drop onto the soil in bunches. A lawn is not a lawn unless it is evenly carpeted with a vigorous growth of grass and when the seed is not spread evenly the grass, of course, will be very uneven, and a poor lawn should be considered as inexcusable a home-feature as a ragged or soiled carpet.

Choose a time carly in the morning or late in the evening when there is no wind, scatter the seed by hand, holding the hand as near to the soil as possible, and let the seed sift out between the fingers as the arm is swung in a semi-circle. Swing the arm both ways, scattering the seed as you go.

The best time to start the lawn is early in the spring. Just as soon as the frost is out of the ground the soil must be thoroughly prepared and as soon as the soil is ready, the seed should be sown. This gives the grass a chance to make 
headway before fall. If the seed is sown late in the season it may not get enough start to hold it over winter.

In severe climates it is best to protect the lawn the first winter. Scatter over it a fairly thick covering of coarse barn yard manure. This will not only give protection from the cold but will also add fertility.

Plenty of moisture should be supplied during the first summer. If rains are not frequent enough to keep the soil well watered, irrigate. In localities where there is little or no rain during the summer, it will be necessary to apply even more water.

This matter of irrigation is an important one and one in which many persons make a mistake. Very often a sprinkler is used to distribute the water but does not do the work well. A circular sprinkler only covers a round space and when it is moved to another part of the lawn there is usually a spot on each side that has not been wet.

The most effective way of watering the lawn is to use a lawn pipe with small nozzles inserted every six inches. When the water is turned into this pipe it is distributed through the various small nozzles and covers the area thoroughly.

This pipe should be raised from the ground three or four feet in order to give the best service. 
The nozzles needed in this system of irrigation may be purchased from any hardware dealer.

Sometimes it is almost impossible to get a lawn started by sowing seed, and when this is so sod must be transplanted. Take the sod up carefully, cutting it in strips about twelve inches wide and thick enough so as not to injure the roots. Cut it into lengths convenient to handle and transplant these where the new lawn is to be made.

See that the surface of the soil upon which the sod is to be laid is perfectly level and well dampened before the sod is put in place. Lay the strips close together and pack them in solid by spanking with the back of a spade. Plenty of moisture must be supplied. The grass will soon take hold and the lawn will be assured.

This method is often resorted to in a lawn on a side hill or a steep bank. Where seed can be sown this plan should not be used because it is more difficult and more expensive to get a real good lawn in this way.

One important caution must be given in the way of fertilizing. If manure is used, only that thoroughly decomposed should be applied. The reason for this is that fresh manure always contains more or less weed seeds. You would not think of taking a handful of weed seeds and scattering 
them on your lawn, but this is practically what you do when you apply fresh barn yard manure. Thoroughly decomposed manure usually has at least a part of the seeds destroyed.

To stimulate the growth of grass on your lawn in spring, hard wood ashes and bone meal should be used as a top dressing. These are always free from seeds and possess the right quantities of elements that the grass usually needs. They should be applied liberally, scattering the mixture on the lawn until it is white. If this is done before a rain, the rain will wash the plant food into the soil and it is at once taken to the roots.

Do not be in too big a hurry to mow your lawn. Young grass should be given a good start before it is cut. It is usually better not to attempt to clip the lawn at all until it is at least three inches high. In fact, it will be better to let it grow even taller than this and then mow it with a scythe:

The first few times you cut your lawn the mowing should be done late in the afternoon or in the evening and the grass left on the lawn for protection for a few days. After the grass has made a good start more frequent cultings -even as often as twice a week - will be a benefit rather than an injury provided, of course, plenty of water is applied. 
A roller is beneficial to a young lawn for two reasons. If it is used after every cutting it will have a tendency to roll out any little hills and in the same way gradually fill up any slight depressions. The leveling of the lawn is not completed when the seed is sown. The work must be continued for a year at least. Moreover, the use of the roller has a tendency to make the grass grow more compactly and a compact sod is exactly what is desired.

For this same reason it is a good plan to use a grass catcher on the lawn mower rather than to rake up the clippings. The use of a rake has a tendency to do just the opposite of the work done by the roller- that is, it pulls the grass out and prevents the establishing of a thick sod.

A grass catcher to fit on the rear of the mower is not very expensive. If you do not care to purchase one it is not a difficult matter to make one yourself. An old gunny sack can be attached to a wire frame that will hang just back of the roller and catch practically all of the clippings. In addition to being rid of them on the lawn, the clippings are worth considerable for chicken feed.

If the grass is cut frequently there will be no harm in leaving the clippings on the lawn, but when it is allowed to grow until it is rather tall 
before it is cut it will be better for the lawn to have the clippings taken away.

Purchase a good lawn mower. You will need it often and if you buy a mower that will last several years you will be able to do better work on your lawn than if you buy a new one every few months.

Get a mower with high wheels. It is easier to rum. Do not purchase one with too wide a cutting bar, however, unless you have an unusually large lawn and must use the wide knife to save time. The small mower will do the best work.

Use plenty of good oil, for the machine will do its best only when it is well taken care of. At least once a year the wheels should be removed and every part thoroughly cleaned. Grass and grit work into the bearings and not only make the machine work hard but make it wear out too quickly.

After the first year it will be necessary to use a heavy roller on the lawn at least once or twice every spring. This is particularly needed in the - colder climates where freezing and thawing has a tendency to crack the soil and make it uneven in places. The heavy roller will level the sod and pack it about the grass roots, making it possible for them to get a good start. A good roller doesn't 
cost much and a very satisfactory kind is one that is filled with water to give it weight. This is more easily handled too, especially when you want to store it for the winter.

Careful watch must be kept on the weeds. There is always a danger of weeds making a start in the lawn. You will never finish with this part of the work. Sometimes weed seeds are brought by the wind, others are brought by birds and other animals. You may even carry some yourself and drop them from your clothing.

Every time you walk across the lawn be on the look-out for weeds. Weeds, in one way, are like a fire: When they are first discovered they are easily destroyed, but if left to make a start, they become a very serious problem.

A good strong knife that can be inserted to some depth below the surface, and one with a $\mathrm{V}$-shaped sharpened point, is the type most useful for grubbing out weeds.

It is easier to remove the weeds on a newly made lawn because the sod and the soil are not packed so firmly, but if the lawn is a few years old it will be more difficult to keep it clear of weeds. For this reason see that the first work is done thoroughly.

Just remember that any plant that is not the 
kind you desire on your lawn is a weed and it should be removed. Sometimes, for example, the lawn beneath a fruit tree will be spoiled by the seeds of the tree dropping into the grass and making a start. The only way to stop this trouble is to dig out the roots and see to it that all the seeds are picked up cverp year before they have an opportunity to take hold.

There are some preparations that will kill weeds, but usually they kill the grass as well, and the only safe place to use them is in a roadway or on a sidewalk.

One of the greatest pests on a lawn is the gopher. A single animal may sometimes destroy a large lawn. The gopher is not contented with making a single opening to his burrow, but continues to throw up dirt and dig holes over all the lawn.

There are only two suceessful methods of getting rid of gophers. One is to place poisoned grain in the openings and the other the use of a poisonous gas. Poisoned grain is perhaps the best because the poisonous gas may easily escape from another opening to the burrow and its value thus be lost.

Sometimes a colony of ants will get into a lawn and destroy parts of it. One of the best methods 
to get rid of ants is to use carbon bisulphide. 'This, however, is a dangerous preparation and must be handled with great caution. It is both poisonous and explosive and will destroy the grass roots with which it comes in contact.

The safest way is to drive a stick into the burrow of the ants and pour in a small quantity of the liquid, then stop up the holes quickly with soil and pack the surface of the hill firmly. This kills the ants, but it will take some time to restore the portion of the lawn they have destroyed.

When the landscape architect puts his materials together,--his lawns, trees, shrubs and flowers, -he is composing pictures in the same sense and the same way as does the landscape painter. And in it all he reflects his personality. It is this pulting of himself into the work that adds to the joy of the work and final accomplishment. Just try it and have some of the joy for yourself. 


\section{Plant Life Series}

A series of monographs for 1914-1915 to create a general interest in agriculture, horticulture, and floriculture with instructions to make it possible for everybody to grow his or her own fruits, flowers, and vegetables, the following being the first twelve titles:

1. Give The Boy His Chance.

2. Start the Boy Right.

3. How Nature Makes Plants to Our Order.

4. Vegetables-From Your Own Garden to the Table or Market.

5. Vegetables-What, and When to Plant-on Your Own Soil.

6. The Joy of Raising Your Own Flowers.

7. Flowers-What, How and When to Plant-At Your Own Home.

8. Two Acres-A Competence with Contentment.

9. Beautify the Lawn to Reflect Your Personality.

10. Better Fruits and More of Them.

11. Small Fruit Growing for Home or Market.

12. Canning, Preserving, Candy Making-Profitable Business Plans for the Folks at Home.

13. Farm Management.

14. Better Grass Crops for Better Live Stock.

15. Improvement in Grains.

These monographs are not for sale. They are issued for distribution to members of The Luther Burbank Sociely, and to others only on recommendation of members 




\section{LIBRARY OF CONGRESS}

||||||||||||||||||||||||||||||||||||||||| 